\title{
Response of Clusterbean (Cyamopsis tetragonoloba L.) to Weed Management Practices and Phosphorus Levels under Sub-tropical Climatic Conditions of Rajasthan
}

\author{
Surendra Kumar Meena ${ }^{1}$, S. L. Mundra ${ }^{1}$, Raghuvir Singh Meena ${ }^{1}$, H. K. Sumariya ${ }^{1}$, \\ Piyush Chaudhary ${ }^{1}$, Tikendra Kumar Yadav ${ }^{2}$ and Narendra Kumawat ${ }^{3 *}$ \\ ${ }^{1}$ Department of Agronomy, Rajasthan College of Agriculture, MPUAT, Udaipur -313 004, \\ Rajasthan, India \\ ${ }^{2}$ Department of Agronomy, Institute of Agricultural Sciences, Banaras Hindu University, \\ Varanasi - 221005 (U.P.) - India \\ ${ }^{3}$ AICRP for Dryland Agriculture, College of Agriculture (RVSKVV, Gwalior), Indore - 452 \\ 001, Madhya Pradesh, India \\ *Corresponding author
}

\section{A B S T R A C T}

\section{Ke y w o r d s}

Weed management, Phosphorus levels, Growth parameters, yield, Economics

Article Info

Accepted:

07 August 2020

Available Online:

10 September 2020
Two field experiments were conducted to evaluate the effect of weed management practices and phosphorus level on growth, yield and economics of cluster bean in consecutive kharif season of 2015 and 2016 at Instructional Farm (Agronomy), Rajasthan College of Agriculture, Udaipur. Field trial was conducted at same site during both the years in split plot design and replicated thrice with eight weed management practice viz. Pendimethalin $1.0 \mathrm{~kg} \mathrm{ha}^{-1}$ as pre-emergence (PE), Pendimethalin $1.0 \mathrm{~kg} \mathrm{ha}^{-1}$ as PE + hand weeding (HW) 30 DAS, Pendimethalin + Imazethapyr $0.8 \mathrm{~kg} \mathrm{ha}^{-1} \mathrm{PE}$, Pendimethalin + Imazethapyr $0.8 \mathrm{~kg} \mathrm{ha}^{-1} \mathrm{PE}+\mathrm{HW} 30 \mathrm{DAS}$, Imazethapyr + Imazamox $0.05 \mathrm{~kg} \mathrm{ha}^{-1}$ at 15 DAS, Imazethapyr + Imazamox $0.05 \mathrm{~kg} \mathrm{ha}^{-1}$ at 15 DAS + HW 30 DAS, two HW at 15 and 30 DAS and weedy check in main-plot and four levels of phosphorus i.e. 0, 20, 40 and 60 $\mathrm{kg} \mathrm{ha}^{-1}$ in sub plots. The allocation of treatments among replications, sub blocks and ultimate plots was carried out purely by following the principles of randomization. Results showed that among the various weed control treatments, two hand weedings (HW) at 15 and 30 DAS gave significantly higher growth parameters viz., plant height $(58.68 \& 58.78$ $\mathrm{cm}$ at 50 DAS and $89.48 \& 90.38 \mathrm{~cm})$ and dry matter accumulation plant ${ }^{-1}(10.54 \& 10.61$ $\mathrm{g} \mathrm{plant}^{-1}$ at $50 \mathrm{DAS}$ and 15.02 and $15.23 \mathrm{~g} \mathrm{plant}^{-1}$ at $75 \mathrm{DAS}$ ) which was significantly superior to rest of the treatments, respectively. Similarly, the highest seed yield (1119 and $1134 \mathrm{~kg} \mathrm{ha}^{-1}$ ), haulm yield (2401 and $2399 \mathrm{~kg} \mathrm{ha}^{-1}$ ) and biological yield (3520 and $3533 \mathrm{~kg}$ $\mathrm{ha}^{-1}$ ) were also recorded with tow HW which was closely followed by Pendimethalin 1.0 $\mathrm{kg}$ + Imazethapyr @ $0.8 \mathrm{~kg} \mathrm{ha}^{-1} \mathrm{PE}+\mathrm{HW} 30$ DAS and Imazethapyr + Imazethapyr 0.05 $\mathrm{kg} \mathrm{ha}^{-1}+\mathrm{HW} 30$ DAS. However, the maximum net return ( $₹ 43228$ and $5153 \mathrm{ha}^{-1}$ ) and $\mathrm{B}: \mathrm{C}$ ratio (2.25 and 2.57) was found in Pendimethalin $1.0 \mathrm{~kg}+$ Imazethapyr @ $0.8 \mathrm{~kg} \mathrm{ha}^{-1}$ PE + HW 30 DAS which was closely followed by Imazethapyr + Imazethapyr $0.05 \mathrm{~kg} \mathrm{ha}^{-1}$ + HW 30 DAS during both the respective years. Application of $60 \mathrm{~kg} \mathrm{P}_{2} \mathrm{O}_{5} \mathrm{ha}^{-1}$ recorded significantly higher growth parameters, yields and net returns, however, the maximum $\mathrm{B}$ : $\mathrm{C}$ ratio was noted in $40 \mathrm{~kg} \mathrm{P}_{2} \mathrm{O}_{5} \mathrm{ha}^{-1}$ over rest of the treatments during both years. 


\section{Introduction}

Among the kharif legumes clusterbean (Cyamopsis tetragonoloba L. Taub) is important crop and popularly known as "Guar" in India. It is mostly suitable for arid and semi-arid conditions and cultivated for green vegetables, dry pods, green manure as well as fodder purpose. It is also drought tolerant because of it has deep tap root system which enables to utilize the available moisture more efficiently and offers to sustain under rainfed condition. This crop has ability to flowering and fruiting under short terms water deficit conditions. Due to high capacity to recover from water stress it is one of the best legume crops for the climatic situation of Rajasthan (Kherawat et al., 2013). In India, the major producing state of clusterbean are Rajasthan, Haryana, Punjab, Gujarat and to a limited extent in Uttar Pradesh and Madhya Pradesh. Among these states Rajasthan is the major producing state in the country with ranked first with respect to both area (47.87 lakh ha) and production (27.48 lakh tones) and an average productivity of $465 \mathrm{~kg} \mathrm{ha}^{-1}$ (Anonymous, 2016).

Amongst agronomic factors known to augment crop production, appropriate weed and nutrient management are considered to be the most important. Being a rainy season crop, clusterbean suffers badly due to severe competition by mixed weed flora. These weeds utilize natural resources more efficiently than crop plants to achieve a fast and vigorous growth which results they provide a tough competition to the crop plants. Initial 30 days of sowing is very critical and presence of weeds beyond this results in yield reduction up to 93.22 per cent (Sharma et al., 2016 and Brar, 2018). Therefore, weed control needs to be restored to exploit the yield potential of this crop. Phosphorus is the second most important plant nutrient which plays a vital role in plant growth and development. Its application led to increase in plant height (Kumawat et al., 2009 a, b), extensive root growth (Liang et al., 1996), total dry weight (Kumawat et al., 2009c) and leaf area of clusterbean. Phosphorus also influences the symbiotic nitrogen fixation, yield and quality of clusterbean pods. Phosphorus has positive effect on nodulation (Tilak et al., 2006 and Kumawat et al., 2018) and activity of rhizobia present in root nodules of leguminous plant (Cassman et al., 1980, Vessey, 1994 and Kumawat et al., 2010). Keeping these factors in view, the present investigation was planned with an objective the study the effect of weed management practices and phosphorus on growth, yield and economics of clusterbean.

\section{Materials and Methods}

The present investigation was conducted during kharif 2015 and 2016 at Instructional Farm (Agronomy), Rajasthan College of Agriculture, Udaipur with 8 weed management practices [Pendimethalin $1.0 \mathrm{~kg}$ $\mathrm{ha}^{-1}$ as Pre-emergence (PE), Pendimethalin $1.0 \mathrm{~kg} \mathrm{ha}^{-1}$ as PE + hand weed (HW) 30 DAS, Pendimethalin + Imazethapyr (Ready mix=RM) $0.8 \mathrm{~kg} \mathrm{ha}^{-1} \mathrm{PE}$, Pendimethalin + Imazethapyr (RM) $0.8 \mathrm{~kg} \mathrm{ha}^{-1} \mathrm{PE}+\mathrm{HW} 30$ DAS, Imazethapyr + Imazamox (RM) $0.05 \mathrm{~kg}$ $\mathrm{ha}^{-1} 15$ DAS, Imazethapyr + Imazamox (RM) $0.05 \mathrm{~kg} \mathrm{ha}^{-1} 15$ DAS + HW 30 DAS, two HW at 15 and 30 DAS and weedy check] were allotted in main plots and four phosphorus levels $\left(0,20,40\right.$ and $\left.60 \mathrm{~kg} \mathrm{ha}^{-1}\right)$ in sub plots to evaluate their effects on growth, yield and economics of cluster bean. The experiment was laid out in split plot design with replicated thrice. The experimental site was situated at $24^{\circ} 35^{\prime} \mathrm{N}$ latitude, $74^{\circ} 42^{\prime} \mathrm{E}$ longitude and altitude of $579.5 \mathrm{~m}$ above mean sea level. This region falls under agroclimatic zone IV-A of Rajasthan which possesses typical sub-tropical climatic conditions and characterized by mild winters 
and moderate summers. The soil of experimental site was clay loam in texture and alkaline in reaction ( $\mathrm{pH} 8.0$ and 8.1). The soil was medium in available nitrogen (284.56 and $279.61 \mathrm{~kg} \mathrm{ha}^{-1}$ ) and phosphorus (20.42 and $19.27 \mathrm{~kg} \mathrm{ha}^{-1}$ ) and high in available potassium (322.83 and $319.17 \mathrm{~kg} \mathrm{ha}^{-1}$ ) in 2015 and 2016, respectively. Test crop clusterbean was grown @ $20 \mathrm{~kg} \mathrm{ha}^{-1}$ at $30 \mathrm{~cm}$ row to row and $10 \mathrm{~cm}$ plant to plant spacing.

The growth parameters like plant height and dry matter accumulation plant ${ }^{-1}$ were recorded at 50 DAS and 75 DAS from five plants randomly collected from individual treated plot. After threshing and winnowing seed yield from net plot area was weighed and expressed as $\mathrm{kg} \mathrm{ha}{ }^{-1}$. The haulm yield $\left(\mathrm{kg} \mathrm{ha}^{-1}\right)$ was calculated by subtracting the corresponding seed yield from the biological yield. Pod and haulm was dried completely, weighed and computed for biological yield as $\mathrm{kg} \mathrm{ha}^{-1}$. The harvest index was calculated by formula suggested by Donald and Hamblin, 1976 as given below:

$$
\mathrm{HI}(\%)=\frac{\text { Economic yield }\left(\mathrm{kg} \mathrm{ha}^{-1}\right)}{\text { Biological yield }\left(\mathrm{kg} \mathrm{ha}^{-1}\right)} \times 100
$$

The economics of different treatment combinations were worked out in terms of net returns $\mathrm{ha}^{-1}$ and $\mathrm{B}: \mathrm{C}$ ratio. The expenses incurred during experimentation were computed as cost of cultivation. Gross return was calculated by multiplying the total economic yield ha ${ }^{-1}$ with their current market price. Net return and $\mathrm{B}: \mathrm{C}$ ratio was calculated with the help of the following formula:

Net return $\left(₹ \mathrm{ha}^{-1}\right)=$ Gross return $\left(₹ \mathrm{ha}^{-1}\right)-$ Cost of cultivation (₹ ha ${ }^{-1}$ )

$$
\text { Benefit :cost ratio }=\frac{\text { Net return }\left(₹ \mathrm{ha}^{-1}\right)}{\text { Cost of cultivation }\left(₹ \mathrm{ha}^{-1}\right)}
$$

\section{Results and Discussion}

\section{Effect on growth}

The critical examination of data (Table 1) revealed that weed management treatments brought about a significant improvement in height and dry matter plant ${ }^{-1}$ at 50 and 75 DAS during both years of investigations. Twice hand weeding gave maximum height and dry matter compared with control. Among the various weed management treatments, combined application of Pendimethalin $1.0 \mathrm{~kg}$ + Imazethapyr $0.8 \mathrm{~kg}$ $\mathrm{ha}^{-1}+$ HW 30 DAS and Imazethapyr + Imazethapyr $0.05 \mathrm{~kg} \mathrm{ha}^{-1}+\mathrm{HW} 30$ DAS produced higher plant height and dry matter production plant ${ }^{-1}$ during both the years. This was attributed to their higher weed control efficiency which proved cleaner and more conducive environment for growth of the crop, thereby improvement in nutrient uptake by the crop compared to weedy check. Results are obtained in close conformity with the finding of Singh et al., (2014), Saras et al., (2016), Sharma et al., (2017) and Singh et al., (2020).

Further data revealed that applications of 60 $\mathrm{kg} \mathrm{P} \mathrm{ha}{ }^{-1}$ gave higher values of plant height and dry matter production plant ${ }^{-1}$ which was significantly superior over the rest of phosphorus levels except $40 \mathrm{~kg} \mathrm{P}_{2} \mathrm{O}_{5} \mathrm{ha}^{-1}$ during both the year. The phosphorus is a structural component of the membrane system of the cell, the chloroplast and mitochondria. It is a constituent of ADP, ATP, nuclic acid, phospholipids, and the co-enzyme, NAD, NADP. It stimulates early root development and growth, which helps in plant establishment. It also enhances the development of reproductive parts, thus, bringing about maturity. Obviously the plant supplied adequately phosphorus levels produced more leaves and recorded higher accumulation of photosynthates yielding higher dry matter production. Increasing in 
plant height and dry matter accumulation with increase levels of phosphorus are in close conformity with the finding of several researchers are Ayub et al., (2013), Bhathal and Kumar, (2016) Verma et al., (2017a), Singh et al., (2017) and Kumawat et al., (2019).

\section{Effect on yields}

Data indicated that weed management treatments and phosphorus levels significantly increased seed, halum, biological yield and harvest index of clusterbean over weedy check during both the years (Table 2). Two hand weeding again proved superiority in respect to seed, haulm, biological yield and harvest index in comparison to rest of the treatments. Among the herbicidal treatments, the maximum seed, haulm and biological yield was obtained with Pendimethalin + Imazethapyr (RM)@0.8 $\mathrm{kg} \mathrm{ha}^{-1}$ along with one hand weeding (HW) at 30 DAS which was found significantly superior over the rest of treatment except Imazethapyr + Imazamox (RM)@ $0.5 \mathrm{~kg} \mathrm{ha}^{-1}+$ hand weeding.

Table.1 Effect of weed management practices and phosphorus levels on plant plant height, plant dry matter $(\mathrm{g})$ and harvest index of cluster bean

\begin{tabular}{|c|c|c|c|c|c|c|c|c|c|c|}
\hline \multirow[t]{3}{*}{ Treatments } & \multicolumn{4}{|c|}{ Plant height (cm) } & \multicolumn{4}{|c|}{ Plant dry matter plant ${ }^{-1}(g)$} & \multirow{2}{*}{\multicolumn{2}{|c|}{$\begin{array}{c}\text { Harvest Index } \\
(\%)\end{array}$}} \\
\hline & \multicolumn{2}{|c|}{$50 \mathrm{DAS}$} & \multicolumn{2}{|c|}{75 DAS } & \multicolumn{2}{|c|}{50 DAS } & \multicolumn{2}{|c|}{75 DAS } & & \\
\hline & 2015 & 2016 & 2015 & 2016 & 2015 & 2016 & 2015 & 2016 & 2015 & 2016 \\
\hline \multicolumn{11}{|l|}{ Weed management practices } \\
\hline Pendimethalin $1.0 \mathrm{~kg} \mathrm{ha}^{-1}$ & 51.45 & 51.64 & 80.16 & 80.50 & 8.54 & 8.58 & 11.04 & 11.01 & 29.43 & 30.79 \\
\hline $\begin{array}{l}\text { Pendimethalin } \mathrm{kg} \mathrm{ha}^{-1}+ \\
\text { HW } 30 \text { DAS }\end{array}$ & 55.77 & 55.89 & 83.11 & 83.37 & 10.03 & 9.97 & 14.01 & 13.94 & 31.00 & 30.87 \\
\hline $\begin{array}{l}\text { Pendimethalin } 1.0 \mathrm{~kg}+ \\
\text { Imazethapyr } 0.8 \mathrm{~kg} \mathrm{ha}^{-1}\end{array}$ & 53.30 & 53.50 & 82.53 & 82.90 & 9.56 & 9.58 & 12.33 & 12.28 & 31.90 & 33.15 \\
\hline $\begin{array}{l}\text { Pendimethalin } 1.0 \mathrm{~kg}+^{-1} \\
\text { Imazethapyr } 0.8 \mathrm{~kg} \mathrm{ha}^{-1}+ \\
\text { HW } 30 \text { DAS }\end{array}$ & 57.55 & 57.78 & 86.95 & 87.19 & 10.21 & 10.30 & 14.56 & 14.61 & 32.59 & 32.71 \\
\hline $\begin{array}{l}\text { Imazethapyr + } \\
\text { Imazethapyr } 0.05 \mathrm{~kg} \mathrm{ha}^{-1}\end{array}$ & 52.36 & 52.42 & 80.97 & 81.86 & 9.18 & 9.23 & 12.01 & 11.96 & 33.20 & 32.45 \\
\hline $\begin{array}{l}\text { Imazethapyr + } \\
\text { Imazethapyr } 0.05 \mathrm{~kg} \mathrm{ha}^{-1}+ \\
\text { HW } 30 \text { DAS }\end{array}$ & 56.36 & 56.43 & 86.46 & 86.95 & 10.19 & 10.04 & 14.37 & 14.60 & 32.39 & 33.15 \\
\hline Two HW 15 and 30 DAS & 58.68 & 58.78 & 89.48 & 90.38 & 10.54 & 10.61 & 15.02 & 15.23 & 31.11 & 32.07 \\
\hline Weedy check & 48.59 & 48.77 & 76.33 & 76.82 & 5.54 & 5.49 & 7.72 & 7.65 & 24.27 & 22.38 \\
\hline SEm \pm & 1.49 & 1.34 & 2.30 & 2.34 & 0.24 & 0.24 & 0.31 & 0.38 & 1.06 & 0.85 \\
\hline $\mathrm{CD}(\mathrm{P}=\mathbf{0 . 0 5})$ & 4.52 & 4.06 & 6.99 & 7.09 & 0.72 & 0.72 & 0.95 & 1.15 & 3.21 & 2.59 \\
\hline \multicolumn{11}{|l|}{ Phosphorus (kg ha $\left.{ }^{-1}\right)$} \\
\hline 0 & 50.49 & 50.53 & 75.64 & 75.36 & 8.53 & 8.55 & 10.78 & 10.81 & 27.88 & 30.18 \\
\hline 20 & 53.86 & 54.10 & 82.52 & 83.00 & 8.97 & 9.02 & 12.20 & 12.22 & 31.51 & 30.93 \\
\hline 40 & 56.20 & 56.31 & 85.86 & 86.53 & 9.54 & 9.52 & 13.54 & 13.58 & 31.76 & 31.30 \\
\hline 60 & 56.47 & 56.66 & 88.97 & 90.08 & 9.87 & 9.81 & 14.01 & 14.02 & 31.80 & 31.36 \\
\hline SEm \pm & 0.81 & 0.72 & 1.08 & 1.25 & 0.13 & 0.14 & 0.17 & 0.17 & 0.34 & 0.23 \\
\hline $\mathrm{CD}(\mathrm{P}=\mathbf{0 . 0 5})$ & 2.31 & 2.04 & 3.07 & 3.55 & 0.38 & 0.39 & 0.50 & 0.47 & 0.95 & 0.66 \\
\hline
\end{tabular}


Table.2 Effect of weed management practices and phosphorus levels on yield and economics of cluster bean

\begin{tabular}{|c|c|c|c|c|c|c|c|c|c|c|}
\hline \multirow[t]{2}{*}{ Treatments } & \multicolumn{2}{|c|}{$\begin{array}{c}\text { Seed } \\
\text { yield } \\
\left(\mathrm{kg} \mathrm{ha}^{-1}\right)\end{array}$} & \multicolumn{2}{|c|}{$\begin{array}{l}\text { Haulm } \\
\text { yield } \\
\left(\mathrm{kg} \mathrm{ha}^{-1}\right)\end{array}$} & \multicolumn{2}{|c|}{$\begin{array}{l}\text { Biological } \\
\text { yield } \\
\left(\mathrm{kg} \mathrm{ha}^{-1}\right)\end{array}$} & \multicolumn{2}{|c|}{ 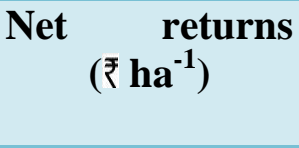 } & \multicolumn{2}{|c|}{$\begin{array}{l}\text { B:C } \\
\text { ratio }\end{array}$} \\
\hline & 2015 & 2016 & 2015 & 2016 & 2015 & 2016 & 2015 & 2016 & 2015 & 2016 \\
\hline \multicolumn{11}{|l|}{ Weed management practices } \\
\hline Pendimethalin $1.0 \mathrm{~kg} \mathrm{ha}^{-1}$ & 637 & 674 & 1521 & 1516 & 2158 & 2190 & 20911 & 25931 & 1.22 & 1.50 \\
\hline $\begin{array}{l}\text { Pendimethalin } \mathrm{kg} \mathrm{ha}^{-1}+\mathrm{HW} \\
\text { 30 DAS }\end{array}$ & 963 & 986 & 2155 & 2203 & 3118 & 3189 & 36914 & 42974 & 1.85 & 2.14 \\
\hline $\begin{array}{l}\text { Pendimethalin } 1.0 \mathrm{~kg}+ \\
\text { Imazethapyr } 0.8 \mathrm{~kg} \mathrm{ha}^{-1}\end{array}$ & 820 & 854 & 1744 & 1718 & 2564 & 2572 & 31023 & 36633 & 1.82 & 2.13 \\
\hline $\begin{array}{l}\text { Pendimethalin } 1.0+ \\
\text { Imazethapyr } 0.8 \mathrm{~kg} \mathrm{ha}^{-1}+\mathrm{HW} \\
30 \text { DAS }\end{array}$ & 1107 & 1131 & 2294 & 2331 & 3401 & 3463 & 44711 & 51539 & 2.25 & 2.57 \\
\hline $\begin{array}{l}\text { Imazethapyr + Imazethapyr } \\
0.05 \mathrm{~kg} \mathrm{ha}^{-1}\end{array}$ & 809 & 800 & 1625 & 1667 & 2434 & 2468 & 30583 & 34093 & 1.85 & 2.04 \\
\hline $\begin{array}{l}\text { Imazethapyr + Imazethapyr } \\
0.05 \mathrm{~kg} \mathrm{ha}^{-1}+\text { HW } 30 \text { DAS }\end{array}$ & 1062 & 1099 & 2225 & 2221 & 3287 & 3320 & 43228 & 49895 & 2.22 & 2.56 \\
\hline Two HW 15 and 30 DAS & 1119 & 1134 & 2401 & 2399 & 3520 & 3533 & 42774 & 49417 & 1.91 & 2.18 \\
\hline Weedy check & 374 & 386 & 1105 & 1324 & 1478 & 1710 & 8342 & 11568 & 0.54 & 0.76 \\
\hline SEm \pm & 34 & 26 & 84 & 76 & 97 & 82 & 1816 & 1506 & 0.09 & 0.08 \\
\hline $\mathrm{CD}(\mathrm{P}=\mathbf{0 . 0 5})$ & 104 & 80 & 255 & 229 & 296 & 249 & 5509 & 4568 & 0.28 & 0.23 \\
\hline \multicolumn{11}{|l|}{ Phosphorus $\left(\mathrm{kg} \mathrm{ha}^{-1}\right)$} \\
\hline 0 & 643 & 725 & 1581 & 1627 & 2224 & 2352 & 21635 & 29308 & 1.24 & 1.67 \\
\hline 20 & 863 & 861 & 1845 & 1878 & 2708 & 2738 & 32709 & 36840 & 1.79 & 2.00 \\
\hline 40 & 960 & 964 & 2036 & 2069 & 2995 & 3033 & 37347 & 42345 & 1.94 & 2.18 \\
\hline 60 & 980 & 982 & 2074 & 2117 & 3053 & 3099 & 37551 & 42533 & 1.86 & 2.09 \\
\hline SEm \pm & 12 & 9 & 32 & 26 & 38 & 32 & 655 & 575 & 0.03 & 0.03 \\
\hline $\mathrm{CD}(\mathrm{P}=\mathbf{0 . 0 5})$ & 34 & 27 & 90 & 73 & 109 & 90 & 1864 & 1636 & 0.09 & 0.08 \\
\hline
\end{tabular}

Similarly, the higher harvest index was noted with Pendimethalin + Imazethapyr (RM) @ $0.8 \mathrm{~kg} \mathrm{ha}^{-1}+1 \mathrm{HW}$ at $30 \mathrm{DAS}$ which was found significantly superior over weedy check and Pendimethalin $1.0 \mathrm{~kg} \mathrm{ha}^{-1}$, however, in 2016 this value was achieved significantly highest with Pendimethalin + Imazethapyr (RM) @ $0.8 \mathrm{~kg} \mathrm{ha}^{-1}$ over the weedy check, Pendimethalin $1.0 \mathrm{~kg} \mathrm{ha}^{-1}$ and Pendimethalin $1.0 \mathrm{~kg} \mathrm{ha}^{-1}+$ HW 30 DAS. This might be due to better weed management which rendered favourable condition like increased availability of nutrient, moisture, light and other factors to the crop plant, which resulted in better growth and higher dry matter production of plants. Due to minimum crop weed competition two hand weeding (at 15 and 30 DAS) recorded maximum seed yield, haulm yield and total biological yield which was expected. These results are in line with Deshmukh et al., (2014), Sharma et al., (2017) and Poornima et al., (2018).

The application of $60 \mathrm{~kg} \mathrm{P}_{2} \mathrm{O}_{5} \mathrm{ha}^{-1}$ gave the highest seed yield, haulm yield as well as biological yield which were found 
significantly higher over the other phosphorus levels except $40 \mathrm{~kg} \mathrm{ha}^{-1}$ during the years. This might be due to higher application of phosphorus, the process of tissue differentiation from stomatic to reproductive, meristematic activity and development of floral primordial might have been enhanced causing greater number of flowers which later developed in pods. Phosphors requirement of pod and developing seeds is met by mobilization of pre-assimilated nitrogen from subtending leaves. It is well known fact that developing pod receives most of photosynthate from subtending leaves. In addition, under higher supply of nutrients, this might be more efficient translocation of photosynthates from leaves via stem to stalk site that is the pod and the seeds. This resulted in higher number of seeds, which on maturity became bold with higher test weight and finally increased the yield. Similar results with phosphorus were also recorded by Yadav et al., (2014), Meena et al., (2015), Bhathal and Kumar (2016), Verma et al., (2017b), Singh et al., (2017) and Kumawat et al., (2018).

\section{Effect on economics}

The net returns and $\mathrm{B}: \mathrm{C}$ ratio significantly influenced by weed control treatments and phosphorus levels during both the years (Table 2). Among the various weed control treatments, mixture application of Pendimethalin + Imazethapyr (RM) @ $0.8 \mathrm{~kg}$ $\mathrm{ha}^{-1}$ with one HW gave significantly highest net return and $\mathrm{B}: \mathrm{C}$ ratio however, it was found at par with Imazethapyr + Imazamox @ $0.05 \mathrm{~kg} \mathrm{ha}^{-1}$ with $1 \mathrm{HW}$ at $30 \mathrm{DAS}$ and $2 \mathrm{HW}$ at 15 DAS and 30 DAS. The low investment coupled with good economic yield might be the reason for higher net returns and $\mathrm{B}: \mathrm{C}$ ratio of these treatments combinations. Similar findings were also reported by Lhungdim et al., (2013), Chandrakar et al., (2014) and Punia et al., (2017).
The further data revealed that application of $60 \mathrm{~kg} \mathrm{P} \mathrm{P}_{2} \mathrm{O}_{5}$ ha $^{-1}$ gave highest net returns while, $\mathrm{B}: \mathrm{C}$ ratio was recorded in $40 \mathrm{~kg} \mathrm{P}^{-1}$ during both the years (Table 4.2). These results are agreement with Singh et al., (2014), Singh et al., (2017), Kumawat et al., (2018) and Kumawat et al., (2020).

It is concluded that application of Pendimethalin $1.0 \mathrm{~kg}$ + Imazethapyr $0.8 \mathrm{~kg}$ $\mathrm{ha}^{-1}$ with one hand weeding at 30 DAS and 40 $\mathrm{kg} \mathrm{P}_{2} \mathrm{O}_{5} \mathrm{ha}^{-1}$ may be recommend for obtaining higher productivity and profitability of clusterbean under sub-tropical climatic conditions of Rajasthan.

\section{References}

Anonymous 2016. Agricultural Statistics at a Glance, Directorate of Economics \& Statistics, Department of Agriculture \& Cooperation, Ministry of Agriculture, Government of India.

Ayub M., Ali S. A., Tahir M., Tahir S., Tanveer A. and Siddiqui M.H. 2013. Bacterial inoculation and phosphorus application on forage yield and quality of clusterbean (Cyamopsis tetragonoloba L.). Intern. J. Modern Agric., 2: 26-33.

Bhathal S. and Kumar R. 2016. Response of integrated nutrient management on growth, yield and yield attributing characters of clusterbean (Cyamopsis tetragonoloba (L.) Taub.) under irrigated conditions of Amritsar. Intern. J. Manage. Social Sci., 4: 42-49.

Brar S. K. 2018. Effect of weed management practices on the performance of clusterbean [Cyamopsis tetragonoloba (L.) Taub] Agric. Sci. Digest, 38: 135138.

Cassman K. G., Whitney A. S. and Stockinger K. R. 1980. Root growth and dry matter distribution of soybean as affected by phosphorus stress, nodulation, and nitrogen source. Crop Sci., 20: 239-244.

Chandrakar D. K., Chandrakar, Kusum, Nagre S. K., Singh A. P. and Nada H.C. 2014. 
Effect of different weed management practices on weed dynamics and performance of rajmash. In: Biennial Conference of Indian Society of Weed Science on - "Emerging Challenges in Weed Management", February 15-17, 2014. DWSR, Jabalpur. pp. 196.

Deshmukh J. P., Shingrup P. V., Kubde K. J., Bhale V. M. and Thakare S. S. 2014. Efficacy of pre and post-emergence herbicides against weed flora in soybean. In: Biennial Conference of Indian Society of Weed Science on "Emerging challenges in weed management", February 15-17, 2014. DWSR, Jabalpur. pp. 80.

Donald C. M. and Hamblin J. 1976. The biological yield and harvest index of cereals as agronomic and plant breeding criteria. Adv. Agron., 28: 361-405.

Kherawat B. S., Lal M., Agarwal M., Yadav H. K. and Kumar S. 2013. Effect of applied potassium and manganese on yield and uptake of nutrients by cluster bean (Cyamopsis tetragonoloba). J. Agric. Phys., 13: 22-26.

Kumawat N., Kumar R. and Sahu Y. K. 2018. Yield, economics and soil health of mungbean as influenced by organic manures and phosphorus levels. Find. Agric. Res. Manag. J., 1 (1): 10-13.

Kumawat N., Kumar R. and Sharma O. P. 2009a. Nutrient uptake and yield of mungbean [Vigna radiata (L.) Wilczek] as influenced by organic manure, PSB and phosphorus fertilization. Environ. Ecol., 27 (4B): 2002-2005.

Kumawat N., Sharma O. P. and Kumar R. 2009b. Effect of Organic manure, PSB and Phosphorus fertilization on yield and economics of mungbean. Environ. Ecol., 27 (1): 5-7.

Kumawat N., Sharma O. P., Kumar R. and Kumari A. 2009c. Response of organic manures, PSB and phosphorus fertilization on growth and yield of mungbean. Environ. Ecol., 27 (4B): 2024-2027.

Kumawat N., Sharma, O. P., Kumar R. and
Kumari A. 2010. Yield and yield attributes of mungbean [Vigna radiata (L.) Wilczek] as affected by organic manures, PSB and phosphorus fertilization. Environ. Ecol., 28 (1A): 332-335.

Kumawat N., Yadav R. K., Bangar K. S., Tiwari S. C., Morya J. and Kumar R. 2019. Studies on integrated weed management practices in maize: A review. Agric. Rev., 40 (1): 29-36.

Kumawat N., Yadav R. K., Singh M., Dudwe T. S. and Tomar I. S. 2020. Effect of phosphorus and bioinoculants and their residual effect on succeeding chickpea (Cicer arietinum) cropping system. Indian J. Agric. Sci., 90 (2): 320-325.

Lhungdim J., Singh Y. and Singh, P. D. 2013. Integration of chemical and manual weed management on density, yield production and economics of lentil (Lens culinaris Medikus). International Journal of Bio-resource and Stress Management 4: 593-598.

Liang Y., Chen P. Y., Leang Y. L., and Chen P. Y. 1996. Effect of soil water nitrogen and phosphorus on root and seedling growth of wheat. Acta Agron. Sinic., 22: 476-482.

Meena B. K., Hulihalli U. K. and Sumeriya H. K. 2015. Growth, yield attributes and yield of medium duration pigeonpea hybrid ICPH-2671 as influenced by fertility levels and planting geometry. Leg. Res., 38: 816-820.

Poornima S., Siva Lakshmi Y., Ram Prakash T. and Srinivas A. 2018. Weed management through early postemergence herbicides to improve productivity and nutrient uptake in greengram. Indian J. Weed Sci., 50: 8284.

Punia R., Punia S. S., Sangwan M. and Thakral S. K. 2017. Efficacy of Imazethapyr applied alone and its mixture with other herbicides in greengram and their residual effect on mustard. Indian $J$. Weed Sci., 49: 151-155.

Saras P., Patel B. D., Armar K. S. and Patel, R. 
B. 2016. Weed management in late kharif clusterbean (Cyamopsis tetragonoloba (L.) Taub) and its impact on crop growth and yield. Intern. J. Bioresou. Stress Manage., 7: 47-51.

Sharma K., Rawat G. S., Gaur D. and Sharma A. 2017. Effect of post-emergence herbicides on weed control, growth and yield of clusterbean [Cyamopsis tetragonoloba (L.) Taub.] in M.P. Agric. Sci. Digest, 37: 179-184.

Sharma N. K., Mundra S. L. and Kalita S. 2016. Yield and nutrient uptake in soybean as influenced by weed management. Indian J. Weed Sci., 48: 351-352.

Singh A. K., Singh R. S., Singh A. K., Kumar R., Kumawat N., Singh N. K., Singh, S. P. and Shanker R. 2020. Effect of weed management on weed interference, nutrient depletion by weeds and production potential of long duration pigeonpea (Cajanus cajan L.) under irrigated. Intern. J. Curr. Microb. Appl. Sci., 9 (1): 676-689.

Singh A. K., Singh R. S., Singh S. P., Kumawat N. and Kumar R. 2017. Productivity, profitability and soil health of pigeonpea as influenced by phosphorus levels and bioinoculants under eastern Uttar Pradesh. Intern. J. Curr. Microb. Appl. Sci., 6 (6): 1723-1732.

Singh A., Jat N. L., Singh R. and Pal S. 2014. Effect of fertility levels and bioinoculants on productivity, profitability, quality and nutrient acquisition of clusterbean (Cyamopsis tetragonoloba). Indian J. Agron., 59: 485-488.

Tilak K. V. B. R., Ranganayaki N. and Manoharachari C. 2006. Synergistic effects of plant-growth promoting rhizobacteria and Rhizobium on nodulation and nitrogen fixation by pigeon pea (Cajanus cajan). European J. Soil Sci., 57: 67-71.

Verma G., Kumawat N. and Morya J. 2017b. Nutrient management in mungbean [Vigna radiata (L.) Wilczek] for higher production and productivity under semiarid tract of Central India. Intern. J. Curr. Microb. Appl. Sci., 6 (7): 488-493.

Verma G., Singh M., Morya J. and Kumawat N. 2017a. Effect of N, P and biofertilizers on growth attributes and yields of mungbean [Vigna radiata (L.) Wilczek] under semi-arid tract of Central India. Intern. Archi. Appl. Sci. Technol., 8 (2): 31-34.

Vessey J. K. 1994. Measurement of nitrogenase activity in legume root nodules: in defense of the acetylene reduction assay. Plant Soil, 158: 151-162.

Yadav S. K., Patel A. G. and Yadav B. L. 2014. Yield, quality and soil fertility of clusterbean (Cyamopsis tetragonoloba L.) as influenced by various row spacing and levels of phosphorus. Adv. Res. J. Crop Improv., 5: 101-104.

\section{How to cite this article:}

Surendra Kumar Meena, S. L. Mundra, Raghuvir Singh Meena, H. K. Sumariya, Piyush Chaudhary, Tikendra Kumar Yadav and Narendra Kumawat. 2020. Response of Clusterbean (Cyamopsis tetragonoloba L.) to Weed Management Practices and Phosphorus Levels under Sub-tropical Climatic Conditions of Rajasthan. Int.J.Curr.Microbiol.App.Sci. 9(09): 748-755. doi: https://doi.org/10.20546/ijcmas.2020.909.094 